\title{
Help-Relationship in Chinese Society: The Perspective of Modernization Development
}

\author{
Xiaorui Wang \\ Beijing College of Social Administration, Beijing, China \\ Email: xrwwy@sina.com
}

How to cite this paper: Wang, X.R. (2020) Help-Relationship in Chinese Society: The Perspective of Modernization Development. Open Access Library Journal, 7: e6609. https://doi.org/ 10.4236/oalib.1106609

Received: July 13, 2020

Accepted: August 25, 2020

Published: August 28, 2020

Copyright ( $) 2020$ by author(s) and Open Access Library Inc.

This work is licensed under the Creative Commons Attribution International License (CC BY 4.0).

http://creativecommons.org/licenses/by/4.0/ (c) (i) Open Access

\begin{abstract}
The help-relationship in Chinese society has undergone social changes under the different historical backgrounds of traditional society and modern society. The family-based help-relationship in traditional society has also become more system-oriented under the tide of modernization. On the one hand, the main body of the system emphasizes the six-element development model led by the state. The institutional development path emphasizes the urban-rural integration and informatization. The rules of system operation emphasize the values of fairness and justice.
\end{abstract}

\section{Subject Areas}

Sociology

\section{Keywords}

Help-Relationship, Modernization, Family-Based, System-Oriented

\section{1. 概述}

当前从求 - 助角度进行福利体制研究的基础还比较薄弱。一是研究的数 量不多。在以 “求助” 为主题进行知网期刊论文查询时候, 涉及求助相关主 题的只有少量文章。二是从宏观制度角度进行求助模式分析的高质量文献更 为有限。由搜集到的文献分析可知, 其中有从具体服务领域做的研究分析 [1] [2] [3]，从制度的角度对求助模式做的分析则少之更少 [4] [5] [6]。

王思斌教授主要是从制度和文化的角度对中国社会的求助关系进行了分 析, 并且认为助人系统分为民间系统和政府系统两个系统, 民间系统具有差 序格局的特征，政府系统具有身份隶属的特征。李迎生、方舒则在《中国社 会工作模式的转型与发展》一文中指出, 计划经济体制下的中国社会工作模 式具有以职业身份为基准的差序格局的特点。本文作者认为, 从鸦片战争到 
辛亥革命, 从中华人民共和国成立到计划经济和市场经济建设, 我们都不应 该忽视现代化发展对中国社会所具有的重大意义。与传统社会相比, 伴随现 代化对人们社会生活的纵深介入, 社会的治理理念、治理结构以及求助系统 都发生了根本改变, 家庭为本的求 - 助关系逐渐为制度为本的求 - 助关系所 取代。

\section{2. 现代化发展背景下中国社会求 - 助实践的逻辑变迁: 一种可能的分析框架}

中国社会的求 - 助结构是内嵌于中国社会的社会结构中的, 社会结构就 是指一个群体或一个社会中的各要素相互关联的方式[7]。这里有群体、组织、 社区和制度等四类实体要素和规范要素 [8]。社会结构建立的标准是完整, 是 大同, 是个人能从团体中获得他生活需要的高度满足 [9]。一旦社会结构满足 不了团体成员的生活需要, 即团体成员所处的经济形态和生活条件的改变对 团体成员的生活造成一定程度的冲击, 且冲击力足够大时, 维持社会结构稳 定的价值理念将会发生根本改变, 由此导致社会结构和求 - 助结构发生相应 的改变。所以考察中国社会的求 - 助实践, 就是考察不同历史时期社会结构 的变迁及其背后的价值理念的变迁, 就是考察不同时期经济形态的历史变迁。

中国经济形态的根本改变发生在近代。中国近代发展滞后, 现代化成为 自清末国门被迫打开一直困扰中国人的生死命题。现代化使人类社会从农业 文明过渡到工业文明, 虽然其本质是技术革命, 第一次现代化是以机器大生 产的工业化为标志, 第二次现代化以信息技术革命为标志, 但它根本上改变 了人与土地的关系，使人与土地的关系逐步改变为人与资本以及人与信息的 关系。它推动并产生了世界资本主义与社会主义两种生产生活方式, 也促使 职业福利、制度福利和残余福利等保障形式的产生。当然现代化带来的是国 家政治经济和社会领域的深刻变革, 比如市场领域的法制化, 政治领域的民 主化、福利化和均等化, 社会领域的都市化。它能够促使该国经济以一定数 率持续增长, 公民社会的集中形成, 有利于世俗理性精神的发育和形成新的 成就动机发展模型。但与现代化所带来的进步相比, 现代化的社会都或近或 早、或多或少地出现了同一类问题: 资源枯竭、犯罪、孤独、焦虑和非人格 化, 过分都市化、老龄问题、离婚问题等等 $[10]$ 。正如美国经济学家萨缪尔森 说过, 市场既没有心脏也没有大脑, 既没有理智也没有良心 [11]。现代化也是 无意识的, 如何解决现代化带来的不良后果, 实现现代性以及中国传统中 “完 整的和大同的” 的美好愿景, 关键是增强对经济增长带动的社会其它部分变 革,即经济增长的社会结果的管控和管理。而制度现代化和个体现代化将是通 往此路的一个必然选择。制度现代化是指面对市场经济时期的 “社会转型陷 阱”，通过市场经济、民主政治和民族国家构筑更加平等自由的制度为本普 惠型的社会保障制度; 所谓人的现代化是指适应现代化建设的需要, 增强个 体的独立性、主体性和技术理性[12]。个体现代化是解决现代化发展背景下个 体原子化问题, 增强个体抗挫能力和服务他人服务社会的精神; 制度现代化 是指通过制度建设解决现代化发展过程中遇到的结构性难题, 比如城乡二元 发展问题、国家与社会发展问题，以及现代化发展视角下求助结构改变等问 
题。一定意义上现代化是具有正向的矢量演化, 在自然 - 经济 - 社会 - 国家 一世界的历史演进中, 它使世界越益成为一个整体积极向前演进。

作为整体世界的一部分, 纵观中国的现代化历程, 历尽坎坷和艰辛, 虽 大起大落, 但逐步推进, 从未间断。中国现代化历程从时间序列上大致可分 为传统社会的前现代化发展时期和现代化发展背景下的近代和现代的现代化 发展时期。传统社会, 在明清时期, 江南发达地区曾出现零星的资本主义萌 芽[13]，但由于文化上的保守和生产资料及其经济权力的官有制，中国并没有 产生近代资本主义，也即没有开启中国的现代化历程 [14]。鸦片战争以后，伴 随外国企业的进入，外国经济的入侵，旧有的家族关系也瓦解了。采用西方 式的小家庭模式合乎社会潮流及经济利益。当中国从农业、前现代化国家迈 向准工业化、现代化社会时, 大家庭体系和家族社会也就不复存在了 [15]。当 国家干涉家庭关系时, 家族社会的政治支撑也就土崩瓦解了。随着而来的, 是以家族为中心的社会的法律支援也崩溃了。怎样去利用现代技术和怎样同 时建立一个和技术相配的社会结构，成为两个不可分的问题 [9]。民国政府明 确提出反对宗族救助, 主张建立国家的公共福利事业。新中国成立初期更是 反对皇权、族权、绅权和神权，逐步限制和取消了民间救助。国家第一次建 立起统一的社会结构体系，在化解原有社会阶级矛盾的基础上，形成了以国 家为依托身份为本和单位为本的求助体系 [16]。

在此基础上，本文考查了中国不同历史时期的求助结构，在中国现代化 历程经历了由中国传统的农业社会到工业社会信息社会等历史性变革后, 家 庭为本、皇权至上的求助结构和社会结构已发生根本性改变，国家和人民共 和的结构体制和制度为本的求 - 助体制更加符合现代化发展背景下国家和人 民的需要。鉴于篇幅所限，本文拟形成以下分析框架(图 1): 第一部分阐述现 代化发展背景下中国社会求 - 助关系的逻辑变迁; 第二和第三部分分别阐述 中国传统社会和现代化背景下中国社会的求 - 助实践; 第四部分阐述中国社 会的求助结构和特点; 第五部分为结论及启示。

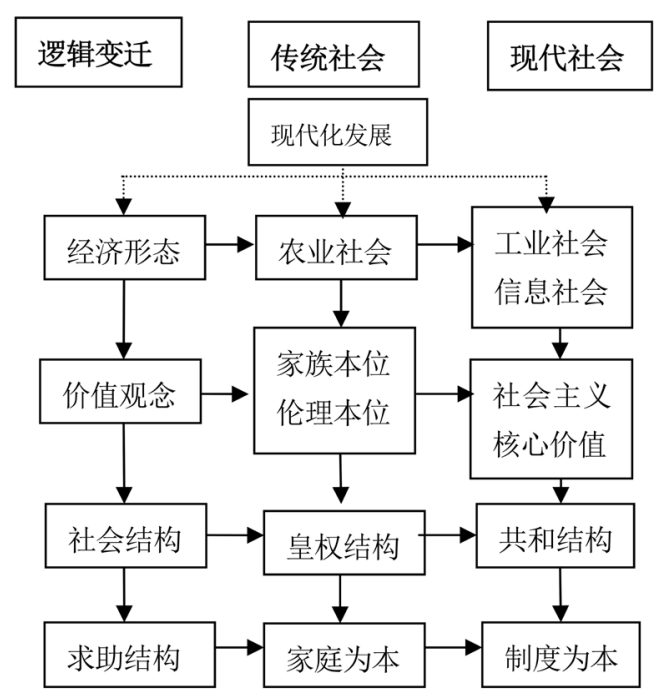

图 1. 中国社会求 - 助实践的逻辑变迁 


\section{3. 家庭为本: 中国传统求 - 助关系分析}

中国传统社会有指秦以降到辛亥革命持续两千余年的中国封建社会, 也 有指 1840 年之前的中国社会[8] [17]。从 1840 年鸦片战争中国被动走上现代 化的坎坷道路视角看 [18], 本文所指的中国传统社会主要是指中国现代化建设 之前的社会, 也即 1840 鸦片战争之前的中国社会。中国传统社会结构的特征 大致可以概括为五点: 稳定性、封闭性、刚性、整合性和二元一体性[8]。传 统社会属于农耕经济, 家族社会, 自给自足是传统农业社会基本的生产生活 方式。梁漱溟先生说: “中国人就家庭关系推广发挥, 以伦理组织社会” [19]。 家应指同居的共同生活的亲属团体而言, 范围较小, 通常只包括二个或三个 世代的人口, 一般人家, 尤其是耕作的人家, 因农地亩数的限制, 大概一个 家庭只包括祖父母, 及其已婚的儿子和未婚的孙儿女, 在子女未婚嫁以前很 少超过五六口以上的。以父宗而论, 则凡是同一始祖的男系后裔, 都属于同 一宗族团体, 概为族人 [20]。家族之外的官场之内的官僚和官场之外的士绅, 主宰着政治和社会各个领域。社会分层呈现出 “士、农、工、商” 四大功能 性等级及多级体系。四个等级之上是政府官僚, 之下是贱民。因虽有阶层划 分, 但没有种姓制度, 科举考试使得各个阶层之间具有一定的流动性, 所以 仍是一个公平的社会 $[21]$ 。

中国在几千年的文化传统中形成了重亲情、重伦理的感性化社会结构, 从社会结构的血缘地缘和业缘关系图谱看, 由家庭本位、伦理本位到职业分 途, 中国传统社会家庭为本的求 - 助体系呈现明显差序格局的特征。家庭家 族成为人们共同抵御自然灾害和疾病困苦的最主要防线。人们 “由家而族, 由族而乡党，凡同居或共财的称为 “家庭”, 五服之内的成员称为 “家族”, 五服以外的共祖族人成为 “宗族” ” [22]。即使由科举形成的绅权和业缘关系 产生的商帮和行会也一定意义上是建立在同乡基础上形成的社区治理维形和 社会组织踓形。比如考取功名的绅士负责基层社会的保甲控制、地方防卫和 诸如经营社仓义仓、兴立乡校义学等社会救济和教化等事务; 商帮和行会内 部一般互帮互助, 此外对于家乡还从事救灾赈荒、办学助读、建桥修路等慈 善事业。此外民间宗教团体和非宗教宗族民间慈善团体也开展有慈善活动, 比如开办养济院、育㚣堂等, 不过这些都是中国传统社会求 - 助结构中的比 较弱的一环。

从另一个方面看, 从国家形成之初, 就已经形成了完整的国家福利制度 建设的理念和实践, 这与西方社会具有明显的不同。比如《周礼 - 地官司徒》 明确提出 “一曰慈幼; 二曰养老; 三曰振穷; 四曰恤贫; 五曰宽疾; 六曰安 富” “保息六政” 的社会福利思想, 《管子・入国》中 “老老、慈幼、恤孤、 养疾、合独、问病、通穷、振困和接绝” 的 “九惠之教” 更是提出了一套系 统的社会福利制度体系建构[23]。救助实践上仓储制作为中国传统社会主要救 助措施, 建立仓库, 储藏谷物, 灾年赈济灾民, 自西周起, 历代相沿 [24]。换 个思路看, 我们这里的国家救助其实是家庭概念的外化, 皇权受宗法制度影 响, 借助父权加强皇权和行政权的同时 [25], 在一定程度上承担着社会救助的 责任, 国家在家庭和国家力不从心的情况下通过官办、民办官助和民办等各 
种形式, 建立起了兒底的社会救助体制, 虽然其性质是解决温饱医疗等拾遗 补缺型的生存救助, 其目的是社会稳定和社会控制。

\section{4. 制度为本：现代化发展背景下的求 - 助关系}

如果从 1840 年鸦片战争中国被动现代化开始, 中国的现代化经历了从被 动到主动, 从依附到赶超, 从准备开始到全面建设等历史过程。其中 1949 年 建国之前的历史时期可以称为早期现代化时期 [26]。早期现代化时期的洋务运 动主张器物层面上的变革, 辛亥革命和民国时期则提倡制度和文化层面的变 革。但由于近代中国社会结构没能接受同一制度化规则的支配, 社会结构体 系内部包含的社会不平等没有得到控制和改善[27], 所以现代化进程迟缓。社 会救助领域现代化推进也存在发展的局部性和不平衡性等特点。

首先民国政府孙中山先生反对传统宗族救助, 提倡建立与中国早期现代 化相适应的囊括生老病死等事务的社会公共福利事业。他强调慈善救助事业 的制度化和法制化, 主张颁布条例明确政府职能, 并在内政部设置社会事务 局等开展慈善事业[28]。其次, 西方教会学校引入了西方学科理念和社会工作 专业教育, 比如北京的燕京大学、南京的金陵大学, 并开始服务社会的实践 活动 [29]。最后, 当时的民国政府和仁人志士开展了一系列救亡图存的本土化 探索和实践。南京国民政府成立之初, 就一再表示要遵照总理遗训, 把实行 地方自治作为训政时期的主要工作, 使国家权力下达到乡村社会, 以实现三 民主义[30]。1945 年以后在南方部分省市, 国民政府所代表的国家权力已经 有效地下达于乡村 [30]。民间晏阳初的定县平民教育运动、梁漱溟 “政教合一” 的乡村建设实验和陶行知创办的晓庄学校对中国应该向哪里去都进行了有益 的探索[31] [32]。

社会主义建设时期的现代化则在早期现代化建设基础上, 第一次在社会 深层上建立起统一的制度规则, 通过国家 - 省 - 市 - 县 - 乡镇行政设置, 瓦 解了家(宗)族和乡绅组成的传统社会, 建立统一的政治和经济制度, 重组传 统社会中 “一盘散沙” 的农民, 形成深层统一的社会结构体系 [33]。深层统一 的结构体系以建设工业体系和国民经济体系的工业化建设为目标, 通过自上 而下的机制实行统一的制度化规则, 因而对于个人来说带有很强的外部强制 性, 改变社会地位的渠道和方式非常之少且又非常困难。这样的制度化结构 实际上决定了人们利益状况和利益空间的刚性和封闭性[16]。这样通过单位组 织的运作，国家政权与财产权合一、市场交易权力和行政命令权力的合一, 形成了社会结构与国家政治权力共生的关系。单位组织并不仅仅是一种纯粹 的经济和社会组织, 更多地表现为一种 “组织化” 的统治形式和工具, 是国 家实现统治的一个重要的中介环节[34]。社会个体的求 - 助因身份不同隶属于 不同的集体、单位和城镇居委会中, 即使自 1978 年改革开放以来, 中国社会 结构转型出现了身份体系弱化, 结构弹性增强以及资源配置方式转变 [35], 国 家也一直以单位为抓手进行着国家管理、控制和社会利益的分配。

其次, 中国现代化进程呈现二元结构和发展的不平衡性等特点。这种二 元结构和发展的不平衡性, 往往表现为多过程的同时交错进行和同类过程在 
不同时间、不同地区、不同社会阶层中的反复推进[36]。中国传统社会, 已有 了长期缓慢的资本主义因素的萌芽, 在经济上、文化上都有了某些稚弱的现 代性因素, 在此后 1949 年建国主动全面现代化建设时期, 现代化建设具有整 体性和分层推进的特点, 是一个量变到质变的逐步积累的过程。就目前的改 革历程, 农村农业的现代化是事关现代化全局成败的关键。虽然农民出外打 工和 2006 年全国统一取消农业税, 一定意义上可以看成是工业对农业的反 哺, 但即使 2019 年中国城市化水平提升到 60\% [37], 改变农村与城市发展的 二元经济结构, 实现农村剩余劳动力的转移, 仍然是目前城乡发展的主旋律。 中间仍要面临户籍制度壁垒的跨越、发育产品市场和生产要素市场, 促进农 村农民的就业, 打破城乡僵硬的封闭化体系和有效解决农村空心化和由于征 地拆迁而造成的 “维权上访” 等社会难题。

最后, 1978 年以后伴随中国共产党的思想解放运动及其在经济、政治领 域的一系列改革, 基层社区和社会发展迅速。一方面国家削弱了对社会和个 人的严密控制, 取消阶级身份体系、封闭的组织管理体系和粮油票证供应制 度, 农村家庭联产承包责任制释放了农村的生产力、公有制之外的集体所有 制企业、三资企业、外资企业、私营企业和个体经济发展态势良好, 绝大多 数商品和服务价格的放开、市场的开放, 催生了利益和组织的多元化发展态 势 [38]。另一方面国家在下放基层治理经济权发展权的同时积极加强基层民主 政治建设, 在城市实行街居制, 在农村实行乡镇村委会制, 使国家公共行政 体制渗透至社会各个生活领域, 形成现代化发展所需要的 “总体性社会”。

当社会结构出现统一的单位化运作、二元结构和社会分化等发展态势, 现代化发展背景下的求助结构也发生了深刻变革。变革的方向即由家庭为本 的求助关系向国家救助制度为本的方向发展。制度(institution)是新制度主义 的基本范畴。新制度主义理论学派的代表人物诺斯认为: “制度” 是一个社 会的游戏规则或在形式上是人为设计的构造人类行为互动的约束, 是一系列 被设计出来的规则、守法程序和行为的道德伦理规范[6]。这里有制度实体、 运行规则和价值理念三个层面的含义。制度实体是指国家政府以及在此名义 下包含的各类组织; 运行规则是指在现代化发展背景下, 制度运行的方式方 法; 价值理念是指制度运行所应当遵循的基本的价值伦理和道德准则。

制度为本求 - 助体制建设是现代化发展内在规律的体现。发达国家和发 展中国家的历史实践证明, 尽管现代化起步的时间先后不一, 内外条件也不 完全一样, 但是当其现代化发展到一定阶段, 各个国家的政治、经济、文化、 社会, 以至到个人思想观念都会出现类似现象[39]。西方工业化、城镇化和民 族国家形成初期也是教权衰落王权兴起的时期, 福利和政权关系密切[40]。英 国 1601 年颁布的《济贫法》和 1834 年推行的《新济贫法》都是对工业化时 期社会问题的积极回应, 在福利国家建设过程中, 国家开始承担主要责任。 美国 20 世纪 30 年代实行的罗斯福新政和德国的社会保险方案也是工业革命 阶级调和的产物。近来伴随福利国家发展中遇到的问题, 新自由主义思想抬 头, 欧洲一体化对福利国家亮起的红灯, 使西方的福利国家也在进行积极的 福利多元化转型 [41], 这为我国制度为本求 - 助模式的建立提供了借鉴。改革 开放以来, 伴随中国社会结构由改革前的 “整体型社会聚合体” 演变为 “碎 
片化利益群体” [42], 形成发展中的 “转型陷阱” [43], 社会中由于利益分配 不均、信访及群体性事件频发, 社会矛盾和社会冲突凸显 [44], 应对矛盾问题, 构建一个具有父权或父爱性质的自由平等和公平权威的社会结构和求 - 助结 构成为现代化发展自身内部的一个必然要求。目前我国具体求助模式如图 2 所示。

由图 2 可知, 目前我们国家的求助系统是国家主导, 多元主体的六元模 式。首先从制度实体看既包括国家名义下的政府, 也包括政府名义下的各类 行政、经济和社会组织, 即现行的社会求 - 助体制是国家主导下的主体多元 模式, 是个体在现代化发展过程中, 由于家庭/亲友救助功能的局限, 通过国 家、单位、社区、市场和社会提供的可资利用的资源的一种求 - 助方式。这 里有学者指出福利三元模式, 也有学者提出 “看护四边形” 的福利四元模式。 三元模式是指在西方社会, 家庭、社会福利制度、市场是保障个人福祉的三 个重要组成部分 [45]。也有学者提出看护四边形的四元模式, 即 “看护” 议题 中提到需要家庭/亲属、市场、国家、非营利部门/社区四个部门[46]。根据中 国现代化发展背景下的社会结构分析, 本文作者认为制度为本的求 - 助模式 为国家主导、家庭/亲友、单位、社区、市场和社会六元主体模式。

改革开放之前, 国家通过对社会的家长式控制形成了单位为本和集体性 中介机制, 而改革开放后, 国家治理结构在持续动态重构过程中, 国家一方 面通过对市场让权和对社会确权重构政府、市场和社会的三维结构, 另一方 面通过保留政府定价权、组织准入权, 税收财政、法律和政策杜杆保障着社 会资源的分配与再分配，实现着社会的公平公正 [47]。《中华人民共和国社会 保险法》、 《社会救助暂行办法》和《中华人民共和国慈善法》等一系列法 律和行政法规的颁布完善了社会保障和社会救助立法, 社会保险、社会救助 和社会福利资金发放和服务输送一般下沉到社区这个平台。社区继 “单位人” 转型为 “社区人” 后成为各种社会保障资金发放的终端平台, 也成为继单位 制之后国家社会治理的抓手和微型实验场。其次, 国家仍然主导着涉及国计 民生领域的粮食生产、能源、基础教育和交通运输等行业的生产和职工福利。 信息社会市场与社会呈现出越益紧密的关系, 与以往市场追求经济效益社会 追求社会效益的价值互补不同，他们更多是面对公共危机事件中的价值趋同。 也即在追求效益的过程中两者都追求利他精神的价值实现, 这是后工业社会 的典型特征, 也是社会转型整体性制度设计所需要的关注。国家主导使得国 家通过单位、社区、市场和社会拥有无可比拟的社会资源动员能力，从而能 在微观基础上切实保障起社会的集体福利机制和日常生活安全机制。最后, 对于依然是伦理社会的中国 [48], 家庭仍然是多元模式中最重要的一环。传统 伦理使得家庭依然是社会个体相互依赖的基本细胞。家庭之外传统社会交往 模式依然是亲密社群之间的交往规则, 即各分子间都相互地拖欠着未了的人 情, 来来往往, 维持着人和人之间的互助合作 [9]。一定意义上说家庭承载者 情感维护和日常生活保障等多重角色, 是制度为本求 - 助结构中最重要的一 环。目前伴随国家 2014 年颁布的《社会救助暂行条例》和 2016 年全面二孩 政策的放开无疑也在政策倡导和执行上提升了家庭防护的门槛, 是对目前和 未来出现的比如老年人养老等社会问题的积极应对。 


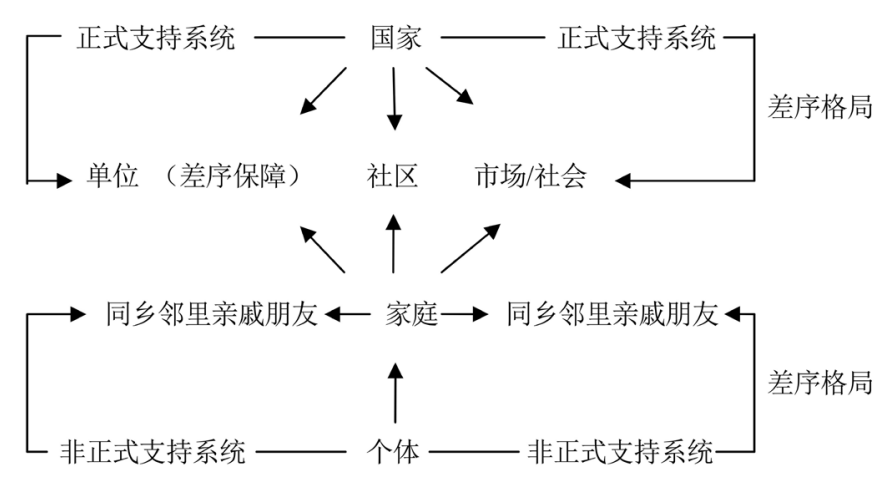

图 2. 目前中国制度为本的求助系统图

其次, 从制度运行的规则来看, 主要有发展路径和运作方式的不同。目 前尽管社会保障城乡统筹发展的具体道路或模式在各国皆有不同，但发展的 目标一一城乡统一或整合——却呈现出较高的趋同性[49]。所以未来中国社会 求 - 助关系从发展路径看, 中国二元分割的城乡壁垒将逐渐消融, 并在此基 础上实现城乡统一的社会保障体制将是未来发展的必然趋势。其次从制度运 作的方式看, 经历过两次现代化发展浪潮, 制度为本的求 - 助结构愈亦呈现 出信息化特征。社会生活通过信息技术手段实现数字化管理, 信息通过链接 多方主体如政府、单位、社区、NGO、家庭以及公民，打破物理障碍，从而 实现了社会保障和社会福利服务领域的提质增效。信息化深刻改变了求 - 助 领域的工作思路和救助方式, 对提升现代化发展背景下福利体制对个体的救 助具有深远的影响。最后, 制度为本的制度实践在感性认识上需要更充分利 用习惯、习俗和惯例等非正式制度因素，使中国传统社会中的情理制度、熟 人制度或 “关系” 制度与正式的理性制度在正式求 - 助系统中有效的衔接和 融合 $[50]$ 。

最后现代化转型期更加强调制度伦理建设。制度建立之初, 就具有了制 度的 “善” 所具有的伦理意义, 否则, 制度建设有何意义呢? 而 “善” 正如 《孟子・滕文公上》中所讲的 “出入相友, 守望相助, 疾病相扶持” 所具有 的意义一样，现代化在社会关系从地方性的场景中 “挖出来” 并在无限的时 空地带中 “再联结” [51]的过程中, 国家、组织和家庭能否为每个个体提供足 够的社会支持, 实现老有所终, 壮有所用, 幼有所长, 鲧塞孤独、废疾者, 皆有所养的制度理想, 这是现代化成功与否的的显著标志。制度伦理在实践 层面的操作所应遵循的基本原则就是公平公正。一方面每个人都公平公正地 受到制度保护, 能够使本民族保持生生不息的创造力和生命活力; 另外一方 面公平公正能够有效化解社会各利益群体之间的利益冲突, 进而有效维护现 代化建设的安全局面[52]。1949 年之后, 稀缺资源配置制度发生了根本性变 化, 用社会主义的再分配经济体制取代了过去以血缘和地缘为基础的配置制 度 [53]。单位为本的救助体制使计划经济和市场经济时期的求 - 助体制明显具 有差序格局的特征。而在国家的社会政策建设方面，其公平性严重不足，不 仅在初次分配领域贫富差距不断扩大，在再分配领域也未能对不合理的分配 格局加以适当矫正; 而且在社会政策内部也存在着这样那样不公平的问题 [54]。因此, 基于公平公正推进我国制度为本的求 - 助体制建设意义重大而且 
具有一定的迫切性。

\section{5. 中国社会的求助结构及特点}

\section{1. 不同历史时期的求助结构分析}

由我国传统和现代社会求 - 助实践发现，不同历史时期的求 - 助方式深 深植根于当时的经济形态、意识形态和社会结构，为此针对不同历史时期的 求 - 助实践, 本文绘制出中国社会求 - 助实践的历史变迁, 如表 1 所示。

\section{2. 求 - 助关系的特点}

\section{1) 传统与现代的混合模式}

吴文藻先生在翻译马林诺夫斯基的《论文化表格》一文时, 强调一个文 化是由三部分组成, 如果我们将其挪用到当前的中国社会, 那么我们可以说 当前中国人的行动意义受到三种力量的影响, 一种是中国传统的, 一种是西 方的, 第三种则是百余年来中西混合所形成的新传统 [55]。现代化发展背景下, 国家建立了统一的社会福利社会保障体制, 公共行政也呈现出现代化发展背 景下的转型特征, 比如工作理念的人本化和法治化、工作决策的科学化和民 主化、工作职能的管理化和服务化、工作手段的科层化和信息化、工作方式 的标准化和专业化。但另外社会大众仍以其习惯经验的实作模式的传统理路 生活, 比如家庭为本的求 - 助路径, 成为两股一体之两面的并存现象 [56]。现 代的力量再怎么地庞大, 却也无法完全颠覆中国文化传统, 更取代不了文化 传统。其实，情形正相反，时间总让传统有消融、乃至虫食 “现代” 的机会， 它以消极隐晦的搓揉手法 “颠倒” 了现代[57]。中国社会从农业社会进展为工 业社会, 可以仍然是伦理社会。经济繁荣不必然带来社会性质变化。建立市 场经济体制也不必然带来社会性质转变[48]。家庭作为社会的基本细胞, 其所 具有的生产生活和救助功能是目前现代性所消融不掉的, 相反在统一的社会 制度和规则下, 现代化却使家庭所具有的救助功能得到了更大程度的发挥和 保障。并进入百姓日常生活中的场域，形塑着行动者的惯习。

表 1. 中国传统和现代社会求-助实践的历史变迁

\begin{tabular}{|c|c|c|c|c|c|}
\hline 年代 & 经济形态 & 价值观念 & 社会结构 & 求-助体系 & 求-助类型 \\
\hline 传统社会 & 小农经济 & $\begin{array}{l}\text { 家庭为本 } \\
\text { 伦理为本 }\end{array}$ & $\begin{array}{l}\text { 族权; } \\
\text { 绅权; } \\
\text { 神权; } \\
\text { 皇权。 }\end{array}$ & $\begin{array}{l}\text { 1) 家庭、家族; } \\
\text { 2) 同乡邻里、绅权; } \\
\text { 3) 宗教民间志愿团体、 } \\
\text { 业缘同行; } \\
\text { 4) 国家 }\end{array}$ & 家庭为本 \\
\hline 计划经济时期 & 计划经济 & 阶级斗争 & $\begin{array}{l}\text { 国家; } \\
\text { 单位; } \\
\text { 集体; } \\
\text { 社区; } \\
\text { 家庭。 }\end{array}$ & $\begin{array}{l}\text { 1) 家庭; } \\
\text { 2) 街坊邻居、亲戚朋友; } \\
\text { 3) 公社乡镇; 单位; 居委会; } \\
\text { 4) 国家 }\end{array}$ & 单位为本 \\
\hline 市场经济时期 & 市场经济 & $\begin{array}{l}\text { 社会主义 } \\
\text { 核心价值 }\end{array}$ & $\begin{array}{l}\text { 国家; } \\
\text { 单位; } \\
\text { 社区; } \\
\text { 社会组织; } \\
\text { 家庭。 }\end{array}$ & $\begin{array}{l}\text { 1) 家庭; } \\
\text { 2) 亲戚朋友邻居; } \\
\text { 3）单位、社区、社会组织; } \\
\text { 4）国家 }\end{array}$ & 制度为本 \\
\hline
\end{tabular}




\section{2) 差序格局}

费孝通先生是这样描述差序格局的: “以 '己” 为中心, 像石子一般投 入水中, 和别人所联系成的社会关系, 像水的波纹一般, 一圈圈推出去, 愈 推愈远, 也愈推愈薄。在这里我们遇到了中国社会结构的基本特征了” [9]。 近年来, 对差序格局的研究, 有从 “事实” 与 “规范” 双层意涵概念的解读; 有稀缺资源配置说; 有人际关系建立和社会结构构成两个维度的分析; 还有 差序格局中的动力学理论分析 [53] [58] [59] [60]。借鉴王思斌教授关于中国社 会求助关系的分析和李迎生关于中国社会工作模式的分析, 本文认为中国社 会的求助关系也呈现出差序格局的特征。

首先从求 - 助关系看, 存在两种性质不同的求 - 助系统, 正式的求 - 助 系统和非正式的求 - 助系统。正式的求 - 助系统是指官方系统, 是指单位、 社区、市场和社会层面的救助; 非正式的求 - 助系统是指民间系统, 主要是 指家庭家族和同乡邻里亲戚朋友的求助。个体遇到困难的求助逻辑一般是先 向非正式系统求助, 如果没有被救助, 然后才向正式系统求助。这里非正式 的求 - 助系统很明显具有传统文化血缘地缘等伦理学意义, 即在求助过程中 亲疏有别。而正式求 - 助结构采用孙立平教授的稀缺资源配置说来分析, 反 映的其实是一种社会资源的分配格局, 其中有企业以职工福利为基准的救助; 有国家社会保险、社会救助和社会福利方面的救助; 还有市场、社会组织和 网络媒体等实施的救助。企业职工福利为基准的救助, 主要是以职业身份为 基准形成的差序格局，其中有公务员及参公管理事业单位人员、国有企业和 一般事业单位员工、集体企业员工、合资企业和私营企业就业员工、城镇非 就业人口和农民等五大类职业划分 [6]。而社会保险、社会救助和社会福利一 般通过社区发放，这里保障资金由于单位不同，保险费用缴纳基数存在不同， 也存在差序格局的特征，反映的是与国家关系的亲疏有别。

总之, 在求 - 助实践中, 在制度与生活的互动中, “差序格局” 模糊了 私人关系与公共利益、正式制度与习惯法的界限, 并工具性地建立各种情感 和道德的共同体，以实现私人或者制度的目的。……总之， “差序格局” 在 制度实践中的作用就是以特殊主义的生活逻辑替代普遍主义的制度逻辑, 即 使其在特定情境中实现了正式制度的目的，但其实质还是造成了正式制度的 差别性实践, 消解了正式制度自我期许的普遍主义的价值基础和合法性。因 此, 以 “差序格局” 为线索洞察制度与生活的互动逻辑, 或者在制度与生活 的互动进程中厘清 “差序格局” 的存续、演变甚至消弭，是把握中国未来求

- 助结构的重要环节 $[61]$ 。

\section{6. 结论}

当代中国用了七十多年的时间, 实现了现代化发展的历史性跨越, 在经 济转型、社会转型和政治转型背景下, 面临着工业化、城镇化、消费社会、 信息社会和风险社会的巨大冲击与挑战, 社会治理任重道远[62]。面对中国社 会求 - 助方式由家庭为本单位为本向制度为本的根本性转变, 怎样在政治经 济和社会等社会治理领域提升救助工作的专业化技术化水平和服务效能, 实 现制度对个体诉求的无缝对接, 切实实践十八大以来社会治理领域 “以人民 
为中心” “以民生为根本” 等根本原则的实现, 是未来我国制度为本求助结 构研究的出发点和落脚点。在此过程中, 我们一方面需要利用已有的制度资 源, 形成现代化发展过程中的制度优势, 另一方面需要通过文化自觉增强现 代化发展的主体意识和危机意识, 从而从容应对现代化和后现代化发展过程 中的治理难题和求 - 助难题。

现代化从西方发展, 逐渐以全球化示人。究其本质在于文化之特殊性。 西方文化是以宗教为根的文化, 是一种横向文化。世俗社会和神权社会并行, 现世的生活是为了未来在另一个世界获得救赎, 所以西方文化是一种未来取 向。正是由于这样的指向, 使得西方人在现世的世界缺乏本体性安全感, 从 而实现了在不断解剖自我 (家庭聚会中实现) 和解剖外界自然的过程中, 实 现了人的觉醒, 开启了世界现代化历程。中西文化是世界的二维格局、纵横 格局, 中国文化是以家为根的文化, 是一种纵向的文化。家谱通过姓氏可以 让我们追踪自己血脉起源到古代, 所以中国文化关注的是过去和现在, 关注 过去是文化上的保守指向, 关注现世是中国文化的世界取向。所以中国文化 早熟, 虽不能主动开启现代化历程, 但制度为本求 - 助结构的传统文化取向, 却能克服现代技术理性的泛滥, 以传统性和后现代性匡正和重构现代性, 重 构当代社会价值规范。正如 “道始于情” [63], 家是情感发生发展的起点和归 点, 人世间万事万物之间的关系从家庭发展而来而又回归于 “家庭” 。家庭 为本的价值伦理强调个体 “礼义廉耻” 的自我价值, 孝悌、谨信和亲仁等个 体交往规则和 “修身齐家治国平天下” 的大同理想, 这无疑更符合技术理性 下社会的本质要求。

其次, 现代性意味着对熟人关系的解构, 关系解构过程中是建立一个更 加公平合理透明的社会秩序还是衍生出一个更大范围的熟人关系圈或者江湖 是现代化转型成功与否的标志。为此我们呼唤更加公平平等的社会政策、更 加公平平等的收入分配办法、更加公平平等的公共财政支出和更加人性化的 信访制度设计, 从而解决诸如城乡之间的二元分割, 社区碎片化 [64]和社会主 体利益多元化等社会 “断裂” 现象 [65]。其次现代化是意识的现代化, 还是制 度和结构的现代化 [66]。目前现代化发展背景下社会治理背景下已经形成了社 会统一性整合框架, 国家行政权力已经有效渗透至乡镇街居层面。目前针对 社会转型与经济转型不同步、社会治理转型与社会转型也不同步的情况下 [67], 社会治理结构如何做好顶层制度设计和底层实践逻辑是对现代化发展的 生死考验, 也是执政党能力的再考验。为此, 必须跨越目前差序格局的制度 误区, 一方面清晰界定社会治理的公共空间边界, 提供相应的制度政策产品 和福利服务产品, 有效保证民众对日常安全保障机制的需要和集体福利保障 的需要。另一方面通过协会社团和草根社会组织的功能发挥、企业公共产品 的生产实现救助功能的主体多元和现代化发展中经济发展、社会发展和人本 身发展的有机统一 $[68]$ 。

\section{基金项目}

北京社会管理职业学院项目(SGYYB2020-22)。 


\section{Conflicts of Interest}

The author declares no conflicts of interest regarding the publication of this paper.

\section{References}

[1] 虞烈东, 袁慧, 崔夏琼. 社会工作参与社会救助领域路径刍议[J]. 中国社会工作, 2018(3): 30-31.

[2] 王伟进. 城乡困难家庭的求助网络及其政策启示 [J]. 人口与经济, 2016(5): 115-125.

[3] 张威. 家庭教育咨询中求助者与助人者的行为特征和互动方式分析与思考一一 基于华仁社会工作发展中心的咨询性社会工作[J]. 社会工作, 2015(12): 47-91.

[4] 王思斌. 中国社会的求助关系一一制度与文化的视角 [J]. 社会学研究, 2001(4): $1-10$.

[5] 马志强. 从熟人关系到专业关系: 社会工作求助模式的转向 [J]. 西北师大学报 (社会科学版), 2014(1): 140-144.

[6] 李迎生, 方舒. 中国社会工作模式的转型与发展[J]. 中国人民大学学报, 2010(3): 101-108.

[7] 戴维.波普诺, 李强. 社会学[M]. 北京: 中国人民大学出版社, 1999: 94 .

[8] 李培林. 关于社会结构的问题一一兼论中国传统社会的特征 [J]. 社会学研究, 1991(1): 77-83.

[9] 费孝通. 乡土中国.乡土重建 $[\mathrm{M}]$. 北京: 群言出版社, 2016.

[10] 张静. 关于现代化的概念 [J]. 社会学研究, 1990(5): 14-25.

[11] 萨美尔森. 经济学[M]. 北京: 商务印书馆, 2012.

[12] 冯建军. 超越 “现代性”的中国教育现代化: 人的现代化视角 [J]. 南京社会科学, 2019(9): 133-137.

[13] 张环. 中国现代化的分期与发轫[J]. 社会学研究, 1991(6): 22-37.

[14] 王海明. 论中国资本主义社会萌芽的独特性[J]. 东南大学学报(哲学社会科学版), 2017, 19(2): 5.

[15] 徐中约. 中国近代史[M]. 香港: 香港中文大学出版社, 2002: 360 .

[16] 李路路, 于显洋, 王奋宇. 现代化过程中的社会结构及其变革一一当代中国制度 化结构试析[J]. 社会学研究, 1991(1): 65-78.

[17] 张玩. 中国现代化的分期与发轫[J]. 社会学研究, 1991(6): 22-37.

[18] 张琭. 发展理论与中国现代化研究述评[J]. 社会学研究, 1989(6): 44-57.

[19] 梁漱溟. 中国文化要义 $[M]$. 上海: 学林出版社, 1987.

[20] 篗同祖. 中国法律与中国社会[M]. 北京: 中华书局, 2003: 2-3.

[21] 徐中约. 中国近代史[M]. 香港: 香港中文大学出版社, 2002: 80 .

[22] 杜正胜. 中国式家庭与社会[M]. 合肥: 黄山书社, 2012.

[23] 王思斌. 社会工作导论[M]. 北京: 高等教育出版社, 2004: 37.

[24] 崔乃夫. 中国民政词典[M]. 上海: 上海辞书出版社, 1990.

[25] 张晋藩, 王超. 中国政治制度史[M]. 北京: 中国政法大学出版社, 1987.

[26] 吴忠民. 关于中国早期现代化的几个问题[J]. 社会学研究, 1991(2): 103.

[27] 李路路, 于显洋, 王奋宇. 对近代中国现代化进程迟缓的社会学结构分析 [J]. 中 国人民大学学报, 1990(6): 53.

[28] 赵晓芳. 慈善文化的变迁: 从社会控制到社会责任[J]. 兰州学刊, 2013(5): 
124-128.

[29] 王思斌. 社会工作导论[M]. 北京: 高等教育出版社, 2004: 45.

[30] 丰箫. 权力与制衡- - 1946 年嘉兴县的乡镇自治 [J]. 社会学研究, 2002(6): 95-107.

[31] 晏阳初, 赛珍珠. 告语人民[M]. 桂林: 广西师范大学出版社, 2003.

[32] 梁漱溟. 乡村建设大意答乡村建设批判 [M]. 北京: 中华书局, 2018 .

[33] 李路路, 于显洋, 王奋宇. 当代中国社会结构的变动与现代化进程 [J]. 天津社会 科学, 1990(6): 36-42.

[34] 李汉林, 李路路. 资源与交换-中国单位组织中的依赖性结构 [J]. 社会学研究, 1999(4): 44-45.

[35] 郑杭生, 洪大用. 当代中国社会结构转型的主要内涵[J]. 社会学研究, 1996(1): 58-63.

[36] 张环. 中国现代化的分期与发轫[J]. 社会学研究, 1991(6): 22-23.

[37] 潘家华, 单菁菁, 武占云. 城市蓝皮书: 中国城市发展报告(No. 12 大国治业之城 市经济转型) [M]. 北京: 社会科学文献出版社, 2019.

[38] 郑杭生, 洪大用. 当代中国社会结构转型的主要内涵[J]. 社会学研究, 1996(1): 63.

[39] 张琭. 发展理论与中国现代化研究述评[J]. 社会学研究, 1989(6): 47.

[40] 周弘. 福利的解析: 来自欧美的启示 $[\mathrm{M}]$. 上海: 上海远东出版社, 1998.

[41] 周弘. 福利国家向何处去[J]. 中国社会科学, 2010(3): 93-112.

[42] 李强. 从“整体型的社会聚合体”到“碎片化”的利益群体一一改革开放 30 年与我 国社会群体特征的变化[J]. 新视野, 2008(5): 15-17.

[43] 清华大学凯风发展研究院社会进步研究所, 清华大学社会学系社会发展研究课 题组. “中等收入陷阱”还是“转型陷阱”[J]. 开放时代, 2012(3): 125-145.

[44] 冯仕政. 社会冲突、国家治理与 “群体性事件”概念的演生 [J]. 社会学研究, 2015(5): 63-67.

[45] 熊跃根. 论国家、市场与福利之间的关系: 西方社会政策理念发展及其反思 [J]. 社会学研究, 1999(3): 57-69.

[46] 周维宏. 社会福利政策的新基本原则: “看护四边形理论”及其研究课题[J]. 社会 政策研究, 2016(1): 111-126.

[47] 何艳玲, 汪广龙. 中国转型秩序及其制度逻辑[J]. 中国社会科学, 2016(6): 55.

[48] 谢遐龄. 中国社会是伦理社会[J]. 社会学研究, 1996(6): 71-80.

[49] 李路路. 30 年中国社会结构变革的独特路径[J]. 人民论坛, 2009(总第 245): 50-51.

[50] 刘少杰. 制度建设是构建和谐社会的根本途径[J]. 社会学研究, 2007(2): 191.

[51] 杨伟民. 在“挖出来”与 “再联结”之间一一中国大陆本土社会工作发展的新局面 [J]. 学海, 2012(2): 67-73.

[52] 吴忠民. 社会公正与中国现代化[J]. 社会学研究, 2019(5): 1-18.

[53] 孙立平. “关系”、社会关系与社会结构 [J]. 社会学研究, 1996(5): 20-30.

[54] 李迎生. 中国社会政策改革创新的价值基础一一社会公平与社会政策 $[J]$. 社会科 学, 2019(3): 76-88.

[55] 周飞舟. 行动伦理与 “关系社会”-—社会学中国化的路径 [J]. 社会学研究, 2018(1): 51.

[56] 叶启政. 传统与现代的斗争游戏[J]. 社会学研究, 1996(1): 32-38.

[57] 叶启政. 再论传统和现代的斗争游戏一一正规化的搓揉形塑[J]. 社会学研究, 
1996(6): 81-90.

[58] 王小章. 重思 “差序格局”一一兼与朱苏力教授商榷[J]. 探索与争鸣, 2019, 1(3): 50-57.

[59] 阎云翔. 差序格局与中国文化的等级观[J]. 社会学研究, 2006(4): 201-213.

[60] 翟学伟. 再论 “差序格局”的贡献、局限与理论遗产 [J]. 中国社会科学, 2009(3): 152-158.

[61] 肖瑛. 从“国家与社会”到“制度与生活”: 中国社会变迁研究的视角转换 [J]. 中国 社会科学, 2014(9): 88-104.

[62] 李友梅. 中国社会治理的新内涵与新作为[J]. 社会学研究, 2017(6): 27-28.

[63] 汤一介. 儒学与“和谐社会”建设[J]. 中国社会科学, 2010(6): 27-32.

[64] 李强. 社区的碎片化-一Y 市社区建设与城市社会治理的实证研究[J]. 学术界, 2013(12): 40-50.

[65] 孙立平. 断裂: 20 世纪 90 年代以来的中国社会[M]. 北京: 社会科学文献出版社, 2003.

[66] 唐光华. 政治文化的沉思者白鲁恂 $[M]$. 台北: 允晨文化实业股份有限公司, 1982.

[67] 李友梅. 当代中国社会治理转型的经验逻辑[J]. 中国社会科学, 2018(11): 60 .

[68] 李友梅. 当代中国社会建设的公共性困境及其超越[J]. 中国社会科学, 2012(4): 132-139. 